\title{
АМІНОКИСЛОТНИЙ СКЛАД МОЛОКА ЗДОРОВИХ КОРІВ ТА ХВОРИХ НА КЕТОЗ
}

\author{
Герун Інеса Володимирівна \\ аспірант \\ Сумський національний аграрний університет (м. Суми, Україна) \\ ORCID: 0000-0002-1674-3410 \\ gerun.inesa@gmail.com
}

Дефріцит білкового харчування є актуальним як до населення країн з сталим економічним розвитком так і до розвиваючих. Проблема якісного та безпечного харчування населення була і залишається не вирішеною в усьому світі. Отже питання збалансування раціонів для населення є одним із найбільш актуальним для створеної при Організації Об'єднаних Націй продовольчої та сільськогосподарської організації (ФАО). Дослідженню амінокислотного складу білків молока корів приділено значна кількість робіт. Наші дослідження та їх результати направленні на виявленні змін амінокислотного складу білків молока за захворювання корів на кетоз та оцінки харчової цінності молока. От же результати наших досліджень показують, що є зміни вмісту в сторону зменшення майже всіх амінокислоти і особливо не замінних які відіграють важливу роль у житті людини так як вони не синтезують ся в організмі. Так, за нашими даними вміст амінокислоти валін зменшений 22,6%. Разом з тим бачимо що зменшився також вміст амінокислоти Фенілаланін на 10,1\%. Амінокислота лейцин при захворюванні на кетоз знаходиться практично на одному рівні. Вміст незамінної амінокислоти ізолейцин за кетозу зменшився на 39,4\%. Наші дослідження показують що кількість треоніну та метіоніну зменшена на 40,2 та 80,7 \% відповідно. В білку молока корів є одна із амінокислот яка вважається напівнезамінною для людини, це - аргінін. При захворюванні на кетоз вміст аргініну зменшений на 33,3 \%. Аналіз результатів дослідження вмісту замінних амінокислот показав що значна їх частина також має негативну тенденцію. Так, вміст таких амінокислот як пролін та гістідін зменшився на 20,9 та 22,3 відповідно. Також на 4 та 13,2 \% відповідно зменшився вміст таких амінокислот як гліцин та глютамінова кислота. Суттєве зменшення вмісту відзначили у таких амінокислот як лізин та тирозин на 40,8 та 69,5 \%. Але нами також відмічено що вміст таких замінних амінокислот як серин та аспаргинова кислота збільшився на 10,5 та 9,5% відповідно. Отже таке захворювання як кетоз корів призводить не тільки до зниження продуктивності а і до втрати біологічної цінності молока та вироблених із нього молочних продуктів.

Ключові слова: білок молока, амінокислотний склад, харчова чінність, захворювання на кетоз, молоко, корови.

DOI: https://doi.org/10.32845/bsnau.vet.2020.3.1

Вступ. Однією з глобальних соціально-економічних проблем $€$ забезпечення населення продуктами харчування. Вирішення цієї проблеми повинно відбуватися на світовому, регіональному та національному рівнях. Харчування було і залишається на першому місці у житті та здоров"ї людини (Hulich, M.P. 2011). В Україні відмічається постійне скорочення дійного поголів'я. За даними державної статистики в 2018 році вироблено молока в межах 10,1 млн. тонн, що в порівнянні з 2009 роком менше на $15 \%$.. Щоправда, темпи падіння виробництва молока знизилися за рахунок використання сучасних технологій. Зменшення падіння виробництва молока пов'язане з підвищенням продуктивності корів. Моніторинг продуктивності корів показує, що за 2018 рік було отримано 6054 кг, а в 2009 році лише 3915 кг. На переробні підприємства протягом 2018-го, надійшло 4,18млн. тонн молока, що менше на 10,5 \% в порівнянні з 2009 роком. Варто підкреслити, що у структурі надходження сировини молока на переробку в межах 78 \% надійшло від великих господарств і лише $22 \%$ від підсобних господарств.

Необхідно відмітити, що за останні роки кількість населення на планеті суттєво збільшилась, разом з тим виникла проблема продовольчого забезпечення людей. Значна кількість розвинених країн все ще справляється з забезпеченням населення харчовими продуктами високої якості та безпечності. Але населення економічно відсталих регіонів не завжди забезпечується висококалорійними харчами з високою біологічною цінністю. Значна частина наукових публікацій вказує, що у населення незадовільний режим харчування, структура харчового раціону і кількість спожитої їжі. У раціоні превалюють дешеві продукти які не можуть повністю

забезпечити організм необхідними поживними речовинами, недостатнім є споживанням м'ясних, молочних, рибних товарів, свіжих овочів та фрруктів. Тому, однією із перших структур ООН ще у 1946 році, створена організація ФАО, яка повинна займатися аналізом та вдосконалення раціонів харчування населення всіх країн, а також розробляти заходи щодо профілактики недостатності. Ця організація приділяє особливу увагу білковим компонентам, якнайбільш необхідним у харчовому ланцюзі людей. Тому питання збалансування білково-вуглеводної складової раціонів харчування жителів різних країн $є$ одним з ключових для створеної при ООН Продовольчої та сільськогосподарської організації (ФАО).

Разом з тим, необхідно відмітити, що засвоюваність білків із різних харчів неоднакова. Отже, ще у 1981 році учасники Об'єднаних консультативних зборів експертів ФАО, ВОО3 та УООН (Університету ООН) запропонували використовувати термін «істинної» засвоюваності білка та навели перші дані щодо величини такої засвоюваності для різних білків. На теперішній час отримані результати лабораторних досліджень на тваринах та людях показують, що величини засвоюваності білків таких, наприклад, як білка молока корів знаходяться у межах $95 \%$.

Аналіз останніх досліджень і публікацій. Численні дослідження вітчизняних та закордонних науковців вказують про суттєву зміну структури раціону корів в Україні та інших державах. Показники вживання м'яса та молочних продуктів суттєво зменшились, що призводить до погіршення харчування населення. Разом з тим виявлене зменшення використання таких незамінних амінокислот як метіоніну, трипто-

Вісник Сумського національного аграрного університету

Серія «Ветеринарна медицина», випуск 3 (50), 2020 
фану і валіну. В раціоні порушено співвідношення між ненасиченими та насиченими жирними кислотами, недостатнє надходження в організм вітамінів А та В2. На теперішній час викликає тривогу суттєве зменшення вживання молока і молочних продуктів (Tsimbalista N.V. та Davydenko N.V., 2008; Hulich M.P., 2011).

Разом з тим молоко отримується не завжди від здорових корів, що впливає на харчову його цінність. Харчова цінність молока залежить у першу чергу від легкозасвоюваних білків, які складаються з амінокислот особливо незамінних для організму людини. Спеціалісти ФАО та ВООЗ провели аналіз амінокислотного складу молока корів та зробили висновок щодо їх харчової цінності. Разом з тим було встановлено кореляційну залежність між загальною засвоюваністю білка та засвоюваністю окремих амінокислот, які містяться у його складі. За даними досліджень ця різниця між величинами не перевищувала $10 \%$. Тому запропоновано рішення щодо внесення кореляційної поправки на істинну засвоюваність білка достатньо для отримання близьких до клінічних результатів. Отже використовувати окремі поправки щодо кожної амінокислоти недоцільно. Експерти Консультативних зборів рекомендували почати масштабну роботу щодо створення бази даних засвоюваності окремих харчових продуктів та раціонів. На теперішній час ведеться робота по покращення різних порід корів В основі покращення молочний білок та вміст амінокислот які б відповідали вимогам потреб людини.

На теперішній час голштинська порода $€$ одна 3 найбільш поширених серед молочної худоби. Унікальність голштинської породи полягає у надзвичайно високому рівні трансформації енергії корму в молоко. На сьогодні, виробники молока використовуючи сучасні наукові розробки та великий потенціал даної породи, намагаються отримати як можна вищу продуктивність за одночасного зменшення витрат на корм. Високий потенціал виробництва молока та добрі адаптивні ознаки корів голштинської породи сприяли її поширенню у багатьох частинах світу (Bankovska N.V., 2008; Borshch 0.0., 2017). При цьому селекціонери часто ігнорували функціональні ознаки голштинів, що призвело до зниження продуктивності у повновікових корів, погіршення стану здоров'я, отже, додаткових витрат на ветеринарні заходи, проблем з відтворенням та тривалістю господарського використання (довговічністю) в цілому по породі. Все це нівелює продуктивні переваги голштинської породи. Нині зростає інтерес до кросбридингу завдяки покращенню функціонального стану помісних корів та складу компонентів молока (Danshy'n V.O., 2016; Dezetter, C., 2015; Ferris, C.P., Heins, B.J., Buckley, F., 2014; Heins, B.J., Hansen, L.B., 2012). Інші аспекти, такі як придатність молока до виробництва певних видів продукції і стійкість до метаболічних та незаразних хвороб, також впливають на те, що цьому напряму розведення дедалі більше віддають перевагу розвинуті країни світу. Значна частина науковців вказує, що у помісних корів першого покоління суттєво підвищуються продуктивність та довголіття, якісний склад молока, показники відтворення (Рубан С.Ю., 2016, 2017). В Україні в останнє десятиліття, активно формуються стада корів голштинської, української чорно-строкатої та червоно-строкатої порід. Продуктивність яких понад 6 тис. кг молока за лактацію. Тварини цих порід добре пристосовані до промислової технології утримання. Але підвищення продуктивності навіть при задовільному утриманні не пройшло для організму тварин непоміченим. В зв'язку з цим на перший план виринуло таке захворювання як кетоз. Це захворювання яке на пряму пов'язано з живленням високопродуктивних тварин, особливо в період пізнього сухостою та в перші дві - три неділі після отелення. Це захворювання призводять до виникнення і розвитку хвороб пов'язаних з порушенням обміну речовин та впливає на стан внутрішніх органів таких як: серце, нирки печінка, ендокринні залоз, роботу шлунково-кишкового тракту, ураження кінцівок тощо. За кетозу молочних корів порушується вуглеводно-жировий, білковий, енергетичний та мінеральний обміну і як наслідок в організмі накопичуються кетонові тіл (ß-оксимасляна, ацетооцтова кислота та ацетон). Разом з тим при дослідження відмічають дистрофічні зміни в печінці, серці, нирках, яєчниках, щитоподібній та прищитоподібній залозах, гіпофізі. Необхідно відмітити, що чим вища продуктивність тим більше кетонових тіл в організмі пряма пропорційна залежність. Виробництво молока це не щось окреме а робота всього організму тому одне тягне за собою інше. Ця хвороба не щось унікальне для України ії реєструють в усіх країнах 3 високорозвиненим молочним тваринництвом, зокрема в таких країнах як США, Канаді та країнах Європи. До цього часу вчені та практики ветеринарній медицині вважають, що захворювання сягає найбільшого розвитку період найвищої продуктивності. Тому пропонують основну увагу звертати на клінічний статус саме в період найвищої лактації. На початку лактації для синтезу молока коровам потрібно більше поживних речовин ніж вони можуть отримати при споживанні корму. Здорова корова на 4 день після отелення використовує енергії на $26 \%$, а білків - на $25 \%$. При виробництві молока корова використовує до 97 \% отриманої енергії та до 83 \% білка і лише незначна частка йде на потреби власного організму. В зв'язку з цим коли корова неспроможна спожити необхідну кількість корму як для виробництва продукції так і для потреб власного організму. В цей період може виникати від'ємний енергетичний баланс. Такий негативний енергетичний баланс може тривати ввесь період підвищення лактації але особливо він небезпечний на ії̈ початку. У період негативного енергетичного балансу дефіцит енергії компенсується за рахунок резервів власного жиру. Внаслідок цього тварина може втрачати до 10-12 \% живої ваги тіла. Це призводить зменшення резистентності організму і як наслідок відповідної реакції на захворювання. Диспансеризація господарств Сумської (ТОВ АФ «Косівщинська»; ДП «ДГ інститут c/г НААНУ»; ТОВ АФ «Хлібодар»; ТОВ АФ «Маяк»; ТОВ АФ «За Мир»; ТОВ АФ «Перемога» та ТОВ АФ «Надія» Чернігівської області показала що захворювання на кетоз виявляють у межах від 24,3до 44,4%. Захворювання частіше виникає у першу - другу неділю після розтелення (Sklyar O.I, Gerun I.V, Kirichek L.V, 2018). Експериментальне зменшення енергетичного балансу на 25 \% проявилося захворюванням на кетоз 80 відсотків корів. Отже дані дослідження показують що основна причина кетозу це дефріцит енергії у раціоні. Разом 3 тим десріцит енергії може зростати з розвитком різних патологічних станів приклад таких як: гіпомагнемія, гіпокальцемія, гіпотонії рубця, мастити, метрити, хвороби кінцівок та інше. На початку лактації надмірний білковий корм і порушення зменшення цукру та крохмалю також призводить до захворювання на кетоз. Разом з тим за даними професора Кондрахіна І.П. суттєву роль у виникненні кетозу корів відіграє ожиріння особливо у період сухостою. За його даними вгодованість корів у період сухостою повинна бути у межах 3,5-3,7 
бала за 5 бальною шкалою. 3 погляду професора Кондрахіна І.П. у ожирілої корови знижений апетит відповідно вона не поїдає необхідну кількість корму для вироблення молока, а значить недостачу енергії компенсує з власного жиру що і приводить до накопичення кетонових тіл.

За нашими даними (Sklyar O.I, Gerun I.V, Kirichek L.V, 2018) при захворюванні на кетоз здебільшого спостерігається на першому місяці після отелення що проявляється зниженням продуктивності, в'ялістю, тахікардією, тахіпное та зменшенням кількості скорочень рубця. Температура тіла не виходить за межі норми але в середньому зменшена $0,7^{\circ} \mathrm{C}$. А як відомо найбільшу кількість продукції та найкращої якості можна отримати лише від здорової тварин. Отже якість та безпечність молока напряму залежить від здоров'я тварини. Однією із найбільш розповсюдженої продукції корів є молоко та молочні продукти вироблені із нього. Які займають найбільший відсоток у структурі раціону людей. Ще колись видатний вчений І.П. Павлов писав, що молоко має не тільки поживні але й лікувальні властивості. Одним із перших харчів у новонароджених $є$ молоко матері. Найбільш розповсюджене у всьому світі є молоко корів. Яке містить у собі не тільки такі компоненти як білки, вуглеводи, жири а й близько $150 \mathrm{iн}-$ ших поживних речовин таких як вітаміни, мікроелементи та макроелементи які використовуються організмом людини в процесі життєдіяльності. Разом з тим, використовуючи молоко та молочні харчі не відповідної якості та безпечності можна нанести суттєву шкоду здоров'ю, так як воно є найкращим поживним середовищем для розвитку патогенних мікроорганізмів. За порушення санітарно-гігієнічних вимог при виробництві, отримання та зберіганні, молоко може стати не придатним для використання. Одним із найбільш розповсюджених захворювань дійного стада яке впливає на якість та безпечність молока $є$ мастит особливо субклінічної форми. Для зменшення захворюваності на мастит на виробництві 3 метою профілактики необхідно використовувати сучасні знання щодо способів і методів доїння та утримання молочного обладнання в належному санітарному стані. Разом 3 тим, одним із важливих показників при виробництві молока $є$ безпечність повітря за мікробним забрудненням. При виробництві молока не завжди звертають увагу на чому тварина віддихає тобто яка підлога наскільки вона забруднена в тому числі і мікроорганізмами. Також одним із чинників який направлений на профілактику виникнення та поширення маститу дезінфекція приміщень, доїльного обладнання та гігієна вим'я тварин. На віть на тепер коли наука зробила значний крок у вивчення маститу стовідсотково не вдається його позбутися на жодній із ферм. Це пов'язано з тим що субклінічний мастит особливо на початку захворювання не має ознак. Через це уражена тварина довгий час може знаходитися у стаді. В наслідок цього через молочне обладнання особливо гуму доїльних стаканів може інфікувати інших тварин у стаді. Разом з тим не всі тварини хворіють навіть маючи збудника як в організмі так і на шкірі при цьому вони є переносниками інфекції. Ось чому неможливо повністю оздоровити стадо повністю. Одним із показників санітарного стану стада є постійний контроль вмісту соматичних клітин у збірному молоці, що дозволяє контролювати здоров'я стада та впливає на якість та безпечність молока. Так за даними Тишківської Н.B. (Tyshkivska N.V., 2014) за розвитку запального процесу в молоці корів збільшується кількість сіалових кислот, що пов'язано зі змінами у структурі білків, зростає кількість імуноглобулінів, як наслідок захисної реакції організму. Масова частка загальних білків вірогідно не змінюється за рахунок сироваткових білків. Наступним показником здоров'я стада $є$ бетагідроксибарбітуратів (БГБ). В свою чергу субклінічний кетоз як і субклінічний масти на перших порах не має клінічних ознак. Це захворювання виникає при порушенні годівлі що призводить до негативного обміну речовин і клінічно не проявляється на початку хвороби. В результаті чого втрачається продуктивність та якість молока. Ось чому контроль дотриманням за годівлею тварин є одним із перших у профілактиці кетозу. 3 цією метою додаванням кормових добавок у складі яких є халатні метали дозволить профілактувати захворюваність на кетоз корів та не допустить зниження якості молока. Отже, систематичний контроль за здоров'ям стада дозволяє отримувати молоко високої якості та безпечності. На теперішній час на ряду з кількістю молока особливу увагу звертають на якість та безпечність. Одним із показників якості є біологічна цінність яка базується на амінокислотному складі білка. Такі білки як казеїн, $\beta$-лактоглобулін і а- лактоальбумін в основному синтезуються у секреторному відділі вим'я. Але частина речовин що йде на синтез білків потрапляє в альвеолярні клітини молока через капілярну сітку із крові. Отже в утворенні молока приймає участь ввесь організм а не лише вим'я. А значить на його якість та безпечність впливає стан здоров'я тварин. За даним P.І. Білик (2007) при захворюванні корів на лейкоз в амінокислотному складі білків молока, відмічається зниження кількісних і якісних показників. Так за його даними у молоці хворих тварин вміст незамінних амінокислот зменшений порівняно до здорової, що вказує на зниження їх синтезу. Разом з тим навпаки збільшення вмісту таких замінних амінокислот як глутамінової, валіну та проліну, порівняно з аналогічними показниками молока контрольних корів.

Мета роботи провести дослідження вмісту амінокислотного складу білків молока корів за захворювання на субклінічний кетоз та порівняти його зі здоровими тваринами.

Матеріали та методи дослідження. Дослідження проводили у ТОВ АФ «Хлібодар» с. Головашівка Сумського району Сумської області на коровах української чорно-строкатої молочної породи другої лактації. Протягом дослідження тварини знаходились в аналогічних умовах. Їм тримали на типовому силосно-сіно-концентратному раціоні. Для досліду тварин відбирали через 20-25 днів після розтелення. Та проводили дослідження крові на вміст кетонових тіл кетанометром. Для цього одноразовим шприцом отримували кров із під хвостової вени на наносили крапельку крові на пластинку яка була уставлена в кетонометри потім зчитували результат вмісту кетонових тіл дисплеї кетонометра - стандартне дослідження. Дослідження амінокислотного складу молока корів проводили в акредитованій лабораторії 201864 ДСТУ ISO/IEC17025. ВЦ ТОВ «TOB експериментальний центр діагностики та лабораторного супроводу «Біолайтс», вул. Ялтинська, буд. 5-6. м. Київ, 02099. Місце проведення випробувань: вул. Б. Хмельницького,135, смт. Баришівка, Київська обл., 07500. Відділ прийому зразків: +38 096 054-86-57.

Методика підготовки проб молока для визначення амінокислотного складу 0,5 мл молока поміщали у кварцову вішалу і додавали 0,5 МП концентрованої соляної кислоти. Гідроліз проводили за допомогою автоматичної системи розкладання проб Milestone Ethos Easy. Після завершення програми гідролізу вміст віал кількісно переносили в мірну колбу на 
10 мл, після чого аліквоту 2 мл доводили в мірній колбі на 10 мл за допомогою буфера з рH 2,2. Аналіз амінокислот проводили на амінокислотному аналізаторі SycamS433 з постколоночною дериватизацією нінгідрином. Довжина хвилі детектування 440 і 570 нм

Отримані дані опрацьовували на комп'ютері в програмі Excel, визначаючи середню арифметичну величину (M), статистичну помилку середньої арифметичної величини (m).
Вірогідність різниць оцінювали за t-критерієм Стьюдента. Результати вважали вірогідними за $\mathrm{P}<0,05-0,001$.

Результати досліджень. В процесі досліджень нами було виявлено 17 амінокислот за якими можна виявити харчову повноцінність білків молока корів хворих на субклінічний кетоз та порівняти їх вміст з білками молока здорових тварин (табл. 1)

Амінокислотний склад білків молока здорових корів та хворих на кетоз

\begin{tabular}{|c|c|c|c|c|c|}
\hline \multirow{2}{*}{$\begin{array}{c}\text { Homep } \\
\Pi / \Pi\end{array}$} & \multirow{2}{*}{$\begin{array}{c}\text { Назва показників, } \\
\text { одиниці вимірювання, мг/г }\end{array}$} & \multicolumn{2}{|c|}{ Результат досліджень (середнє значення 3х тварин) } & \multirow{2}{*}{\multicolumn{2}{|c|}{$\begin{array}{c}\begin{array}{c}\text { Відношення } \\
+/-\end{array} \\
\text { - }\end{array}$}} \\
\hline & & хворі тварини & здорові тварини & & \\
\hline \multicolumn{6}{|c|}{ Незамінні амінокислоти } \\
\hline 1 & Валін & $1,33 \pm 0,045$ & $1,72 \pm 0,054^{* * *}$ & \multicolumn{2}{|c|}{$-0,39$} \\
\hline 2 & Фенілаланін & $1,06 \pm 0,059$ & $1,18 \pm 0,054$ & \multicolumn{2}{|c|}{$-0,12$} \\
\hline 3 & Лейцин & $2,23 \pm 0,089$ & $2,16 \pm 0,031$ & \multicolumn{2}{|c|}{$+0,07$} \\
\hline 4 & Ізолейцин & $0,83 \pm 0,038$ & $1,37 \pm 0,044^{* * *}$ & - & 0,54 \\
\hline 5 & Треонін & $0,58 \pm 0,023$ & $0,97 \pm 0,037^{* * *}$ & - & 0,39 \\
\hline 6 & Метіонін & $0,11 \pm 0,015$ & $0,57 \pm 0,018^{* * *}$ & - & 0,46 \\
\hline 7 & Аргінін & $0,80 \pm 0,029$ & $1,20 \pm 0,038^{* * *}$ & - & 0,40 \\
\hline \multicolumn{2}{|r|}{ Сумарне значення } & $0,99 \pm 0,250$ & $1,31 \pm 0,195$ & - & 0,320 \\
\hline \multicolumn{6}{|c|}{ Замінні амінокислоти } \\
\hline 1 & Пролін & $2,23 \pm 0,094$ & $2,82 \pm 0,063^{* * *}$ & - & 0,59 \\
\hline 2 & Гістидін & $0,73 \pm 0,033$ & $0,94 \pm 0,029^{\star *}$ & - & 0,21 \\
\hline 3 & Гліцин & $0,48 \pm 0,023$ & $0,50 \pm 0,033$ & - & 0,02 \\
\hline 4 & Глутамінова кислота & $4,69 \pm 0,093$ & $5,40 \pm 0,071^{* * *}$ & \multicolumn{2}{|c|}{$-0,71$} \\
\hline 5 & Аспаргінова кислота & $2,08 \pm 0,011$ & $1,90 \pm 0,032$ & \multicolumn{2}{|c|}{$+0,18$} \\
\hline 6 & Аланін & $0,70 \pm 0,092$ & $0,72 \pm 0,039$ & - & 0,02 \\
\hline 7 & Лізин & $2,00 \pm 0,066$ & $3,38 \pm 0,073^{* * *}$ & - & 1,38 \\
\hline 8 & Тирозин & $0,26 \pm 0,015$ & $0,82 \pm 0,023^{* * *}$ & - & 0,57 \\
\hline 9 & Серин & $1,23 \pm 0,069$ & $1,10 \pm 0,046$ & \multicolumn{2}{|c|}{$+0,12$} \\
\hline 10 & Цистин & $0,42 \pm 0,056$ & $0,48 \pm 0,061$ & \multicolumn{2}{|c|}{$-0,06$} \\
\hline & Сумарне значення & $1,482 \pm 0,426$ & $1,806 \pm 0,508$ & \multicolumn{2}{|c|}{$-0,324$} \\
\hline
\end{tabular}

Примітка. $P<-0,001$ до здорових тварин

Як відомо для повноцінного розвитку та життя живого організму амінокислоти, особливо незамінні повинні поступати з кормом. В даному випадку кормом для тварин і особливо для людей $€$ молоко та молочні продукти. Аналізуючи дані табл. 1. видно що вміст незамінних амінокислот суттєво змінений. Наприклад така незамінна амінокислота як валін має менший вміст в порівнянні до здорових тварин на 22,6 \%. Вона необхідна для метаболізму в м'язах та відновленню уражених тканин і підтримування нормального обміну азота в організмі. Разом з тим бачимо що зменшився також вміст амінокислоти Фенілаланін на $10,1 \%$ - це амінокислота є однією із складових білків. Біологічна дія фенілаланіну антидипресантна, покращуючи інтелектуальні функції, обезболююча, зменшення залежності. Організм людини потребує фенілаланін як одну з складових частин усіх білків в організмі. Лейцин одна із амінокислот яку організм ніколи не виробляє сам у даному випадку при захворюванні на кетоз лейцин знаходиться практично на одному рівні. Основна функція лейцину це синтез м'язового білку, вплив на анаболічні процеси та здатність стимулювати виробництво глюкози та інсуліну. Ізолейцин відіграє значущу роль в утворенні енергії за рахунок розщеплення глікогену м'язів, разом з тим не достаток ізолейцину приводить до гіпоглікемії що виражається в'ялістю та сонливістю. Значна його кількість знаходиться в сироваткових білках. Дане дослідження показує що при захворюванні на кетоз її вміст зменшений на 39,4\%. За літературними даними роль треоніну досить різноманітна: бере участь у відкладенні жиру в печінці; регулює обмін жирів, білків і вуглеводів; бере участь у процесах метаболізму; під його дією утворюється колаген необхідний для росту молодняку; сприяє розвитку імунітету, синтезує імунні білки, впливає на білковий обмін. Наші дослідження показують що іїі кількість зменшена на 40,2 \%. Метіонін незамінна амінокислота, яка знаходиться у складі ферментів усіх тканин. Суттєво впливає на стан нирок, зменшує токсичність значної кількості отруйних речовин, відновлює функцію печінки. За захворювання корів на кетоз у білках молока вміст метіоніну зменшується на 80,7 \%. В білку молока корів $€$ також одна із амінокислот яка вважається на-пів незамінною для людини це аргінін. Біологічні шляхи її утворення у організмі людини існують що правда в деяких випадках особливо при захворюванні і в певні періоди життя її утворюється дуже мало а отже вона повинна потрапляти з їжею. Разом з тим близько 40 \% аргініну розщеплюється в тонкому відділі кишечнику і не потрапляє в кров в зв'язку з цим виникає ї̈ дефіцит. При захворюванні на кетоз вміст аргініну зменшений на 33,3 \%. Отже провівши аналіз даних наведених у табл. 1 щодо незамінних амінокислот можна зробити висновки. При захворюванні корів на кетоз у білках молока зменшується вміст практично всіх незамінних амінокислот. Виключення становить лише лейцин. Разом з тим необхідно відмітити, що при захворюванні корів на кетоз виникли зміни також в кількості замінних амінокислот. Проводячи аналіз вміст замінних амінокислот можна констатувати що їх вміст в молоці також зменшений майже усіх крім аспарагінової кислоти та сирину. Так вміст такої амінокислоти як пролін та гістідін зменшився 
на 20,9 та 22,3 \% відповідно. Також на 4 та 13,2 \% відповідно зменшився вміст таких амінокислот як гліцин та глютамінова кислота. Суттєве зменшення вмісту відзначили у таких амінокислот як лізин та тирозин на 40,8 та 69,5\%. Але нами також відмічено що вміст таких замінних амінокислот як серин та аспаргинова кислота збільшився на 10,5 та 9,5 \% відповідно.

Отже можна констатувати що при захворюванні корів на кетоз навіть субклінічної форми настає зниження біологічної цінності молока

Обговорення та інтерпретація дослідження. Молоко один із незамінних продуктів високої біологічної цінності, який супроводжує людину практично все життя. Традиційно для більшості населення України молоко і молочні продукти $€$ одним із основних інгредієнтів раціону. Молоко - продукт який містить всі мікро- та мікроелементи, вітаміни, співвідношення білків, жирів і вуглеводів і всі ці компоненти залежить від добробуту тварини. Під добробутом необхідно розуміти умови утримання тварин, годівлю та стан здоров'я. Отже якісний та безпечний продукт можна отримати лише від здорової тварини. На теперішній час суттєвий вплив на показники якості та безпечності наклало таке захворювання як кетоз. Найбільш частою причиною яка призводить до захворювання на кетоз $є$ мала кількість енергії особливо на початку лактації. Негативне зрушення обміну речовин розпочинається ще в кінці попередньої лактації і продовжується в сухостійний період. Корови більше 4 бали за вгодованістю після розтелення поїдають менше корму а значить одержують суттєво менше енергії. В наслідок цього підвищується мобілізація власного жиру що призводить до накопичення кетонових тіл у організмі. Функція печінки не безмежна вона не може справитися з збільшеним навантаженням, що призводить до отруєння організму. В зв'язку з цим зменшується харчова та біологічна цінність молока. Так сумарна кількість. Наші дані показують що при захворюванні корів на кетоз зменшується вміст майже всіх амінокислот у білках молока. Сумарне зменшення вмісту незамінних амінокислот становить 2,23мг/г, а замінних 3,68 мг/г. Наші дослідження співпадають з даними Білик P.I (2) яка вказує що при захворюванні корів на лейкоз відбувається не тільки зменшення амінокислотного вмісту а й співвідношення їх що призводить до зниження біологічної цінності молока. А.І. Кузін і Є.Н. Закрєпіна
(12) повідомляють що в молоці корів хворих на кетоз, порівняно до здорових суттєво зменшений вміст метіоніну, лейцину, проліну, аспарагінової кислоти, аланіну, тирозину і загального білка. В молоці ж інфрікованих корів знижено вміст загального білка, фенілаланіну, лізину, лейцину, проліну, аланіну і тирозину Разом з тим Кузін А.І., Закрєпіна Є.Н. надали повідомлення, що амінокислотний склад молока корів уражених лейкозом, порівняно до здорових підвищився в середньому на 22,4 \%, таке підвищення виникло за рахунок цистину (на 40,0 \%), аргініну (на 46,6 \%), аланіну (на 48,9\%) і аспарагінової кислоти (на 42,2 \%). і в меншій мірі - за рахунок гістидину (на 5,3 \%) і валіну (на 3,0 \%). Необхідно відмітити що молоко корів уражених лейкозом мало метіоніну більше на 27,4 \% порівняно до здорових молока здорових тварин. Такі розбіжності можна пояснити тим що при дослідженні не враховується деякі фактори. На наш погляд для порівняння результатів дослідження необхідно враховувати годівлю, вік тварин, період лактації, механізм та стадії захворювання.

Висновки: 1. Проведений аналіз біологічної цінності молока здорових корів та хворих на субклінічний кетоз Української чорно-строкатої молочної породи. Встановлено, що у молоці корів уражених субклінічним кетозом суттєво змінюється амінокислотний склад білків. Так сумарне зменшення кількості незамінних амінокислот становить 0,320 мг/г. Сумарне зменшення замінних амінокислот становить 0,324 мг/г.

2. Встановлено що із незамінних амінокислот лише лейцин має тенденцію до збільшення + 0,07мг/г.

3. Серед замінних амінокислот виявили тенденцію до збільшення аспарагінової кислоти та серину на 0,18 та 0,12 мг/г відповідно.

Перспективи подальших досліджень необхідно направити на вивчення амінокислотного складу білків молока корів хворих на клінічний кетоз.

Висловлюємо подяку за підтримку та допомогу у проведенні дослідження керівнику сектору мікологічного дослідження у експертному центрі діагностики та лабораторного супроводу «Біолайтс», к. вет. наук, доценту кафедри ветеринарно-санітарної експертизи, гігієни продуктів тваринництва та патанатомії ім. Й.С. Загаєвського, Білоцерківського національного аграрного університету Тишківській Н.В.

\section{References}

1. Bilyk R.I.( 2007) Mineralnyi sklad ta tekhnolohichni vlastyvosti moloka, otrymanoho vid RID-pozytyvnykh koriv [Mineral composition and technological properties of milk obtained from RID-positive cows] Problemy zootekhniky ta veterynarnoi medytsyny: zbirnyk. Nauka. [Problems of zoo engineering and veterinary medicine: collection. Science], 16 (41), 2, 1, 95-98.

2. Bankovska, N.V. (2008), Hihiyenichna otsinka faktychnoho kharchuvannia dorosloho naselennia Ukrainy ta naukovi shliakhy optymizatsii [Hygienic assessment of actual nutrition of the adult population of Ukraine and scientific study ways to optimization]. Kandydatska dysertatsiia, Natsionalnyi medychnyi universytet imeni Bohomoltsia [Ph. D. Thesis, Bogomolets National Medical University], Kyiv, 16p.

3. Borshch, 0.0. (2017). Influence of various litter materials and premises characteristics on the comfort and behavior of cows. Ukrainian Journal of Ecology. Vol. 7, no. (4), pp.529-535. Available at: https://doi.org/10.15421/2017_156

4. Borshh, O., Ruban, S. (2017). Intensy'vnist' vy'roshhuvannya krosbredny'x tely`cz' za rizny'x texnologij utry 'mannya [Intensity of growth of crossbred heifers for different technologies of retention]. Visnyk Poltavskoi derzhavnoi ahrarnoi akademii [Bulletin of the Poltava State Agrarian Academy]. 4, 63-66.

5. Borshh, O.O., Borshh, O.V. (2017). Vply`v rizny`x variantiv bezpry 'v'yaznogo utry`mannya koriv na vy traty` obminnoyi energiyi v period ny'z'kotemperaturnogo navantazhennya [Influence of different variants of unbounded maintenance of cows on expenses of exchange energy during the period of low-temperature loading]. Naukovo-texnichny 'j byuleten 'IT NAAN [Scientific-technical bulletin NAAS]. 117, 7-14.

6. Danshy`n, V.O. (2016). Ocinka pleminnoyi cinnosti bugayiv-plidny'kiv molochny`x porid [Estimation of breeding value of bulls-breeders of dairy breeds]. Zbirny'k naukovy'x pracz' BNAU [Collection of scientific works of BNAU]. Ser. "Texnologiya 
vy'robny 'cztva i pererobky' produkciyi tvary 'nny'cztva» [Sir. "Technology of production and processing of livestock products"], 2 (126), 110-116. (in Ukrainian)

7. Dezetter, C. (2015). Inbreding and Crossbreeding parameters for production and fertility traits in Holstein, Montbeliearde and Normande cows. Journal of Dairy Science. 98, 4904-4913. DOI: https://doi.org/ 10.3168/jds.2014-8386

8. Ferris, C.P., Heins, B.J., Buckley, F. (2014) Crossbreeding in Dairy Cattle: Pros and Cons. WCDS Advances in Dairy Technology. 26, 223-243.

9. Heins, B.J., Hansen, L.B. (2012). Short communication: Fertility, somatic cell score, and production of Normande $\times$ Holstein, Montbéliarde $\times$ Holstein, and Scandinavian Red $\times$ Holstein crossbreds versus pure Holsteins during their first 5 lactations. Journal of Dairy Science, 95, 2, 918-924. DOI: https://doi.org/10.3168/jds.2011-4523

10. Heins, B.J., Hansen, L.B., De Vries, A. (2012). Survival, lifetime production, and profitability of crossbreds of Holstein with Normande, Montbéliarde, and Scandinavian Red compared to pure Holstein cows. Journal of Dairy Science. 95, 1011-1021. DOI: https://doi.org/ 10.3168/jds.2011-4525.

11. Hulich, M.P. (2011). Balanced diet and healthy lifestyle - key factors maintaining the health of the population [Zbalansovane kharchuvannia ta zdorovyi sposib zhyttia - kliuchovi faktory zberezhennia zdorovia naselennia]. Problemy starenyia y dolholetyia [problems of aging and longevity], 2, 128-132. (in Russian)

12. Kuzin A.I, Zakrepina E.N. (1997). Vplyv leikemii na produktyvnist koriv ta yakist moloka [Influence of leukemia on cow productivity and milk quality]. Veterinarna miditsina [Veterinary medicine], 2, 19-21.

13. Ministry of Health of Ukraine (1999). Normy fiziolohichnykh potreb naselennia Ukrainy znakhodiatsia v osnovnykh kharchovykh rechovynakh ta enerhii [Norms of physiology necessities of population of Ukraine are in basic food substances and energy], available at: www.moz.gov.ua/ua/portal/dn_19991118_272.html. (in Ukrainian)

14. Ruban, S.Yu. (2016). Krosbry'dy'ng yak element vy'sokoprodukty'vnogo molochnogo skotarstva [Crossbreeding as an element of high-yield dairy cattle breeding]. Biologiia tvaryn [Animal biology]. 18, 2, 94-104. (in Ukrainian)

15. Ruban, S.Yu. (2017). Suchasni texnologiyi vy'robny'cztva moloka (osobly'vosti ekspluataciyi, texnologichni rishennya, eskizni proekty') [Modern milk production technologies (features of exploitation, technological solutions, sketch designs)]. Kharkiv, 172 p. (in Ukrainian)

16. Sklyar, O.I, Gerun, I.V, Kirichek, L.V (2018). Hoduvannia koriv yak odyn iz faktoriv ketozu ta vplyv na yakist ta bezpeku moloka [Feeding cows as one of the factors of ketosis and the impact on the quality and safety of milk] visnyk SNAU [Bulletin of Sumy National Agrarian University], 1 (42), 251-254. (in Ukrainian)

17. Tsimbalista, N.V. and Davydenko, N.V. (2008). "The mill of the actual village population is alimen-tatively reinforced", Problemy kharchuvannia, 1-2, 32-35.

18. Tyshkivska, N.V (2014). Vplyv kilkosti somatychnykh klityn u molotsi koriv na pokaznyky yoho bilkovoho skladu [Influence of the number of somatic cells in milk of cows on the indicators of its protein composition]. Visnyk Bilotserkiv. derzhavnyi ahrarniy Universytet [Visnyk Bilotserkiv. state agrarian University, 1, 251-254. (in Ukrainian)

Inessa Gerun, PhD student, Sumy National Agrarian University (Sumy, Ukraine)

Aminoacid composition of milk of healthy cows and cows with ketosis

Protein deficiency is relevant both to the population of countries with sustainable economic development and to developing countries. The problem of quality and safe nutrition has been and remains unresolved around the world. Thus, the issue of balancing rations for the population is one of the most relevant for the Food and Agriculture Organization (FAO) established at the United Nations. A significant amount of work has been devoted to the study of the amino acid composition of cow's milk proteins. Food and Agriculture Organization of the United Nations (FAO). A significant amount of work has been devoted to the study of the amino acid composition of cow's milk proteins. Our research and their results are aimed at identifying changes in the amino acid composition of milk proteins in cows with ketosis and assessing the nutritional value of milk. However, the results of our research show that there are changes in the content in the direction of reducing almost all amino acids and especially non-replaceable ones that play an important role in human life because they are not synthesized in the body. Thus, according to our data, the content of the amino acid valine is reduced by $22.6 \%$. However, we see that the amino acid content of phenylalanine also decreased by $10.1 \%$. The amino acid leucine in ketosis is almost at the same level. The content of the essential amino acid isoleucine in ketosis decreased by $39.4 \%$. Our studies show that the amount of threonine and methionine is reduced by 40.2 and $80.7 \%$, respectively. In cow's milk protein is one of the amino acids that is considered semi-essential for humans is arginine. In diseases of ketosis, the content of arginine is reduced by $33.3 \%$. Analysis of the results of the study of the content of substituted amino acids showed that a significant part of them also has a negative trend. Thus, the content of amino acids such as Proline and histidine decreased by 20.9 and 22.3\%, respectively. Also, the content of such amino acids as glycine and glutamic acid decreased by 4 and 13.2\%, respectively. A significant decrease in the content was noted in such amino acids as lysine and tyrosine by 40.8 and $69.5 \%$. But we also noted that the content of such replacement amino acids serine and aspartic acid increased by 10.5 and $9.5 \%$, respectively. Thus, such a disease as ketosis of cows leads not only to reduced productivity but also to the loss of biological value of milk and dairy products produced from it.

Key words: milk protein, amino acid composition, nutritional value, ketosis, milk, cows

Дата надходження до редакції: 20.10.2020 p. 


\title{
ВИВЧЕННЯ ПОДРАЗЛИВОЇ І ТОКСИЧНОЇ ДІЇ ДЕЗІНФІКУЮЧОГО ЗАСОБУ „СУХОДЕЗ»
}

\author{
Сластьон Дар`я Сергіївна \\ аспірантка \\ Сумський національний аграрний університет, м. Суми, Україна \\ ORCID:0000-0002-8110-3647 \\ slasten_dasha@ukr.net
}

Коцур Олена Володимирівна аспірантка

Сумський національний аграрний університет, м. Суми, Україна ORCID: 0000-0001-7779-9306 kocurelena7@gmail.com

Фотіна Тетяна Іванівна доктор ветеринарних наук, професор Сумський національний аграрний університет, м. Суми, Україна ORCID: 0000-0001-5079-2390

tatiana.fotina@snau.edu.ua

В статmі представлено результати дослідження подразливої та алергенної дії дезінфрікуючого засобу «Суходез» на тварин в лабораторних умовах. Визначено, що препарат Суходез має слабку дію за ступенем відповідної реакції на подразнення у мишей і кролів. Разом з тим препарат при одноразовій обробці приміщення в гранично допустимій концентрації 60 мг/м³ зумовлює помірну подразнюючу дію на слизові оболонки тварин, що дозволяє віднести його до 3 класу небезпеки. А при пероральному одноразовому введенні в дозах 1250, 2500 та 5000 мг/ке маси тіла не викликав загибелі піддослідних мишей та щурів. На цій підставі, засіб «Суходез» можна віднести до 4 класу небезпеки згідно до Міжнародного стандарту, або до категорії 5 за Міжнародною глобальною класифрікацією Global Harmonized System, (GHS) (ЛД50 nри nероральному надходженні перевищує 5000 мг/кг маси тіла).

Ключові слова: дезінфекція, дезінфектант, лабораторія, мікроорганізми, алергія, подразнююча дія

DOI: https://doi.org/10.32845/bsnau.vet.2020.3.2

Вступ. Дезінфекція - це комплекс заходів, спрямований на знешкодження збудників заразних захворювань у приміщеннях та довкіллі. Благополуччя тваринництва, як і будьякої іншої ланки аграрного виробництва, не може бути належним чином забезпечене без застосування дезінфікуючих засобів (Kovalenko V., 2012).

Арсенал засобів для ветеринарної дезінфекції розширюється. Пошук і розробка нових антисептичних і дезінфікуючих препаратів ведеться постійно. Це обумовлено тим, що, по-перше, жоден з існуючих засобів не є ідеальним, по-друге, постійно зростають вимоги споживачів щодо ефективності, по-третє, змінюються умови і технології виробництва, сировинні можливості й, по-четверте, можливо, найголовніше, споживачі все більше уваги приділяють екологічній безпеці та питанню мінімізації загальної токсичності. Все це значно обмежує коло хімічних сполук, які можуть бути використані у виробництві нових дезінфектантів. Сучасний асортимент дезінфікуючих засобів нараховує велику кількість комерційних препаратів, основними діючими речовинами яких є формальдегід, глутаровий альдегід, перекис водню, гідроген пероксид, пергідроль, гідроперит, хлорактивні сполуки, четвертинні амонієві сполуки (ЧАС) та їхні комбінації. Таким чином, аналіз властивостей сучасних дезінфектантів показує, що не існує універсальних засобів, придатних для дезінсрекції, очищення перед стерилізацією і стерилізації всіх об'єктів. Майже всі дезінфекційні засоби мають обмеження за спектром протимікробної дії, сферою використання та ступенем токсичності, а також за впливом на матеріали, з яких виготовлені об'єкти знезараження. (Mandyhra M. et al., 2010; Romanishyna O. et

al., 2010).

При дослідженні ветеринарного дезінфікуючого засобу Суходез, ми опиралися на базу птахівничих підприємств. У птахівничих господарствах дезінфікують: приміщення для птиці, обладнання, інвентар та предмети догляду за птицею, підсобні споруди і територію, спецодяг, тару і транспорт, інкубатори і племінні яйця, пух, перо, забійний пункт і холодильні камери, підстилку і послід, стічні води та ін.

Особливість дезінфекції та дезінвазії птахівницьких об'єктів полягає в тому, що птиця має дуже тісний контакт з обладнанням та інвентарем, а продукти птахівництва сильно поглинають запахи дезінфікуючих засобів. У зв'язку з цим дезінфекцію слід проводити обережно і ретельно. Крім того, при знезараженні птахівничих приміщень, обладнаних засобами механізації, автоматики, електрообладнанням, необхідно вибирати такі дезінфікуючі засоби, які не впливають на металеве обладнання та апаратуру. Особливо важко проводити дезінфекційні роботи в птахівницьких приміщеннях, оскільки там багато важкодоступних для обробки місць. Перед проведенням дезінфекції ретельно прибирають гній, сміття, підстилку, залишки корму, очищають стіни від фекалій і інших забруднень. Щоб менше утворювалося пилу в процесі механічного прибирання, приміщення зрошують водою або дезінфікуючою рідиною. Одна з першорядних завдань ветеринарної санітарії - пошук і впровадження нових дезінфікуючих засобів і схем їх застосування в практику. Дезінфректанти сприяють знезараженню різних об'єктів тваринницьких приміщень, знищення живих переносників збудників багатьох інсрекційних хвороб тварин і людей (комах і гризунів). Однак деякі

Вісник Сумського національного аграрного університету 